\title{
An Analysis of Product Dimensions Out of Specification as Quality Claim Improvement Activity : Application of 8D Method in the Injection Plastic Industry
}

\author{
Pongky Lubas Wahyudi ${ }^{\mathrm{a}}$, Anita Wulandari \\ ${ }^{a}$ Manufacture Technology Department, Universitas 17 Agustus 1945 Surabaya \\ Jl. Semolowaru No.45, Menur Pumpungan, Kec. Sukolilo, Kota Surabaya, Jawa Timur Indonesia 60118 \\ Telephone +62 315931800 Fax : 0315927817 \\ e-mail: pongkywahyudi@untag-sby.ac.id \\ ${ }^{\mathrm{b},}$ Agroindustry Department, Universitas 17 Agustus 1945 Surabaya \\ JI. Semolowaru No.45, Menur Pumpungan, Kec. Sukolilo, Kota Surabaya, Jawa Timur Indonesia 60118 \\ Telephone +62 315931800 Fax : 0315927817 \\ e-mail: anita@untag-sby.ac.id
}

\begin{abstract}
Abstrak
Setiap perusahaan berusaha mencari cara untuk mempertahankan posisi pasarnya dalam lingkungan bisnis yang semakin kompetitif. Untuk menjadi sukses, perusahaan perlu mencapai tujuan dan sasaran untuk mewujudkan visi dan misinya. Laporan klaim perusahaan dalam beberapa tahun terakhir masih belum terpecahkan. Keluhan tersebut penting karena kepuasan pelanggan hanya dapat ditingkatkan jika akar penyebab masalah diidentifikasi dengan jelas. Dalam industri plastik yang memproduksi suku cadang untuk industri otomotif, metode sistematis bernama 8D digunakan untuk menganalisis kesesuaian produk dengan spesifikasinya. Metode $8 \mathrm{D}$ terdiri dari sembilan disiplin pemecahan masalah. Tujuan awal dari metode 8D adalah untuk menghilangkan cacat yang menyebabkan masalah, sehingga mengembalikan kepuasan pelanggan dan meningkatkan kualitas produk yang dihasilkan perusahaan. Penelitian ini menetapkan kesesuaian 8D untuk penyelesaian keluhan pelanggan. 8D melibatkan kerja tim untuk memecahkan masalah dan menggunakan pendekatan struktural 9 langkah. Dengan studi kasus ini total klaim pelanggan pada akhir tahun lalu hingga tahun ini Des 2020 berjumlah nol (0) dan cacat produk dari proses produksi untuk dimensi yang salah berkurang dari $0,07 \%$ menjadi $0,01 \%$.
\end{abstract}

Kata kunci: 8D; Klaim Pelanggan; Perbaikan; Pemecahan Masalah

Abstract

Every company tries to find ways to maintain its market position in an increasingly competitive business environment. In order to be successful, companies need to achieve their objectives and goals to make their vision a reality while adhering to their mission. Company claims report in the few years still haven't solved yet. Such complaints are significant because customer satisfaction can only be improved if the root causes of problem is clearly identified. In the plastic industry that produces parts for the automotive industry, a systematic method named $8 D$ is used to analyze product conformity to specifications. The $8 D$ method consists of nine disciplines problem solving. The original purpose of $8 D$ method was to eliminate the defect causing the problem, thus restoring customer satisfaction and level up the quality level of company. This research established the suitability of the $8 D$ for complaint settlement. $8 D$ involves team work to solve the problem and using a 9-step structural approach. This case study resulted that the $8 D$ is effective. The total customer claims at the end of last year until this year in Dec 2020 totaled zero (0) and process rejection for incorrect dimensions was reduced from $0.07 \%$ to $0.01 \%$.

Keywords: 8D; Customer Claim; Improvement; Problem Solving 


\section{INTRODUCTION}

The industrial revolution, and into the 20th century, a structured approach to the understanding a problem become a topic of great cognitive interest, especially in the field of psychology. Many theories has been developed in Europe and in the US on problem solving, focusing the studies in the field of business, engineering, mathematics, social, personal, design, etc. Each with its own unique approach and method, but of course there will be some common areas.

In the late 80's onwards, such structured approach slowly become more accepted in our daily work process. It also becomes a topic of study in school curriculum, especially business, social, and engineering studies. The structured approach such as 8D method is commonly used in automotive industries (naturally), manufacturing, healthcare and software. The approach such as 8D method with cross-functional teams is very important. Some of important points are making the awareness of the team members, gaining a deeper understanding and having eye-opening revelations. The 8D framework often provides a detailed awareness about problems and long-lasting solutions (Ehie and Sawhney, 2006) [1]. "Whereas Six Sigma focuses on data and process variables, the 8D-TOPS uses crossfunctional teams, looks for root causes, and implements and test permanent corrections or improvements." [1] [10].

The approaches of 8D's are to define a problem, identify its true root causes, and make a long term corrective action preventing the problem from recurring. One of the steps is to make sure the customer is protected by containing all suspected material within your reach. Align your corrective actions with Poka Yoke solutions as far as possible.

\subsection{Definition of 8D}

The 8D consists of 8 disciplines steps for solving problems. It is a highly disciplined approach for resolving chronic and recurring problems. This approach uses cross-functional teams to synergize with each other and provides excellent guidelines to identify the root cause of problem, containment actions implementation, develop corrective actions and preventive actions then carry out these actions in order to make the problem permanently eliminated [2]. The 8D are: isolating from underlying causes which caused the unexpected condition, identifying the contributing factors causing the problem, eliminating systemic factors that cause the problems, keeping teams from jumping straightly to the final conclusions too early, and preventing problem recurrence [5].

The 8D method can be used for solving critical problems, major problems, chronic and recurring problems. The $8 \mathrm{D}$ method usually used when the problem that are very complex and unable to be resolved by a single most experienced person; communication must go across company levels, other departments and/or to customers during and after problem resolution; and usually used when the customer or management requests 8-D implementation.

However, the $8 \mathrm{D}$ is ineffective if being used for non-recurring problems or problems which can quickly be solved by individual effort, problems with known root causes, making a decision between different alternatives solutions, and problems where the simplest and most obvious solution is likely to be the best or adequate solution [9].

Why not apply the 8D to all problems? The 8D problem solving approach will take several weeks to several months in order to solve a problem. It takes people from crossfunctional teams at least from 4 different organizational areas to effectively apply the 8D team problem solving approach (production section, quality, product engineering, marketing, manufacturing section, supplier, etc.), and requires management side to support for allocated time, related resources that may be required, and the authority to make the appropriate and required changes.

\subsection{D Disciplines Steps}

Pre 8D: Recognized the problem that will be solved, a discussion with management and all related leaders is needed to decide and prioritize existing problem to be solved.

The 8-disciplines consists of: [2] [5] [6] [7] [8]

Prepare and Plan for the 8D: Generated plan for solving the problem and determine the prerequisites. 
D1- Establishment of Team:

Establish a team of members with experienced in project development and understand the product/process knowledge very well. Appoint a team leader and a cross-functional team of people with problem-solving skills from different divisions or departments representing the possible origin of cause.

D2- Problem Description:

Clearly specify the problem by identifying in terms what, who, where, when, why, how and how many $(5 \mathrm{~W} 2 \mathrm{H})$. Make sure that all team members understand the problem.

D3- Development of Interim Corrective Actions to Prevent Damage:

Protect the customer from further defect products by blocking and marking the inventory and what is being produced. Also, identify what is in transit and report to the customer. To continue delivery, sort/ rework may be needed. Any rework has to be submitted to and verified by the customer.

D4- Definition and Analysis of Root Causes:

Identify all potential root causes in all possible working area related to machine, man, method, material, measurement and environment that could explain why the problem occurred and why the problem has not been noticed at the time. Brainstorm to identify possible root causes and reasons why the problem occurred and was not detected before shipping to the customer. Verify TRUE root cause(s) based on facts.

D5- Determination of Permanent Corrective Actions:

Confirm that the selected corrective actions make the problem permanently eliminated and no-recurring, so customer will be safe.

D6- Implementation and Validation of Permanent Corrective Actions:

Define and implement the most effective corrective actions, and permanent corrective action. Check if the intended corrective actions solved the problem. Implementing and removing the corrective actions should work as a flip switch for turning on and off the problem.

D7- Preventing the Recurrence of Problem:

The management and operation systems need to modify, review practices and procedures to prevent recurrence of this and similar problems. Review and improve the processes which prevent the recurring issues. Use Lessons Learned concept (Yokoten).

D8- Congratulate and Recognize the Team:

After the team task is completed and project results meet all customer requirement, the team needs to be formally recognized for all collective efforts and thank them formally.

Need to summarize team's experience and knowledge and complete documented information for 8D report [3] [4].

1.3 Supporting tools for analysis

a) 5 W2H FORM

$5 \mathrm{~W} 2 \mathrm{H}$ is used to define and understand the extent of the problem by asking 7 questions:

-WHAT happened?

-WHY is it a problem?

- WHEN did it happen?

-WHO detected it?

- WHERE was it detected?

- HOW was it detected?

- HOW MANY?

b) ISHIKAWA (FISH BONE GRAPH)

The way to gather all possible causes to a problem we are used this structure: 


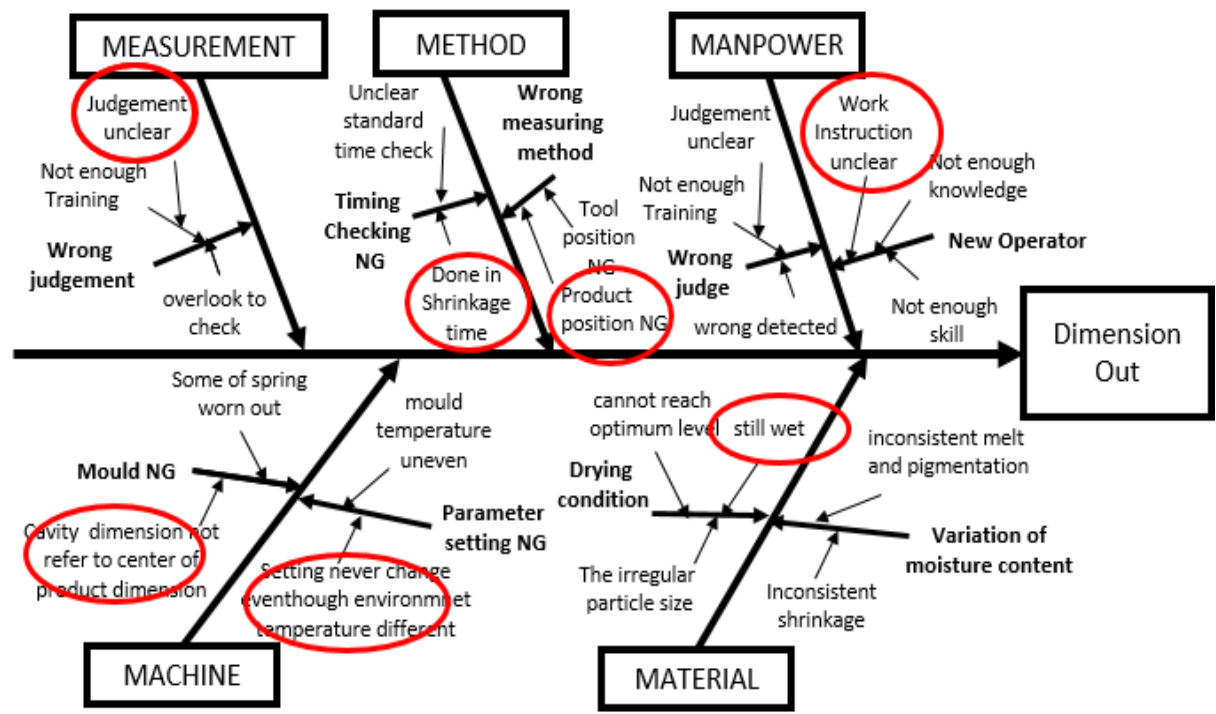

Figure 1.1 Dimension out fishbone graph

c) 5WHY FORM

This question-asking technique is used to find sequential causes for the failure and identify the failure path.

\begin{tabular}{|c|c|c|c|c|c|}
\hline Why & 1 & 2 & 3 & 4 & 5 \\
\hline \multirow{3}{*}{ Occurrence } & $\begin{array}{l}\text { Why did the } \\
\text { problem occur? }\end{array}$ & Why? & Why? & Why? & Why? \\
\hline & \multirow[t]{2}{*}{$\begin{array}{l}\text { Nozzle suction } \\
\text { failed to pick } \\
\text { up drum core }\end{array}$} & $\begin{array}{l}\text { Suction } \\
\text { dirty from } \\
\text { foreign } \\
\text { material }\end{array}$ & $\begin{array}{l}\text { Some of } \\
\text { adhesive } \\
\text { suck by } \\
\text { suction } \\
\text { when drum } \\
\text { core missing }\end{array}$ & $\begin{array}{l}\text { - Machine cannot } \\
\text { stop when drum } \\
\text { core missing } \\
\text { - Cleaning } \\
\text { perform at } \\
\text { suction surface } \\
\text { only }\end{array}$ & $\begin{array}{l}\text { No sensor for } \\
\text { detect drum } \\
\text { core missing }\end{array}$ \\
\hline & & $\begin{array}{l}\text { drum core } \\
\text { not enter } \\
\text { at slider }\end{array}$ & $\begin{array}{l}\text { drum core } \\
\text { dimension at } \\
\text { high limit }\end{array}$ & Material issue & NA \\
\hline \multirow[t]{2}{*}{ Leak out } & $\begin{array}{c}\text { Why wasn't the } \\
\text { problem } \\
\text { detected? }\end{array}$ & Why? & Why? & Why? & Why? \\
\hline & $\begin{array}{l}\text { Taping } \\
\text { operator failed } \\
\text { to detect } \\
\text { stamping } \\
\text { wrong direction }\end{array}$ & $\begin{array}{l}\text { Sequence } \\
\text { checking } \\
\text { is not } \\
\text { standard }\end{array}$ & $\begin{array}{l}\text { Sequence } \\
\text { checking } \\
\text { does not } \\
\text { include in } \\
\text { process } \\
\text { control items }\end{array}$ & $\begin{array}{l}\text { Sequence checking } \\
\text { is not clearly } \\
\text { highlighted into } \\
\text { operation } \\
\text { instruction }\end{array}$ & $\begin{array}{l}\text { Sequence } \\
\text { checking } \\
\text { does not } \\
\text { include in } \\
\text { FMEA study }\end{array}$ \\
\hline
\end{tabular}




\section{METHOD OF RESEARCH}

A series of phases that are used in this research is $8 \mathrm{D}$ with supporting tools for analysis:

Table 2.1 Customer Claim Report

\begin{tabular}{|c|c|c|cc|}
\hline No. & Claim & 2018 & 2018 & 2020 \\
\hline 1 & Dimension Out & 1 & 2 & 2 \\
\hline 2 & Silver Mark & 1 & 0 & 0 \\
\hline
\end{tabular}

Table 2.2 In-proses dimension out defect (Jul - Sept 2020)

\begin{tabular}{|c|c|c|cc|}
\hline No. & Type of Defect & Jul & Aug & Sept \\
\hline 1 & Dimension Out & $0.02 \%$ & $0.09 \%$ & $0.07 \%$ \\
\hline
\end{tabular}

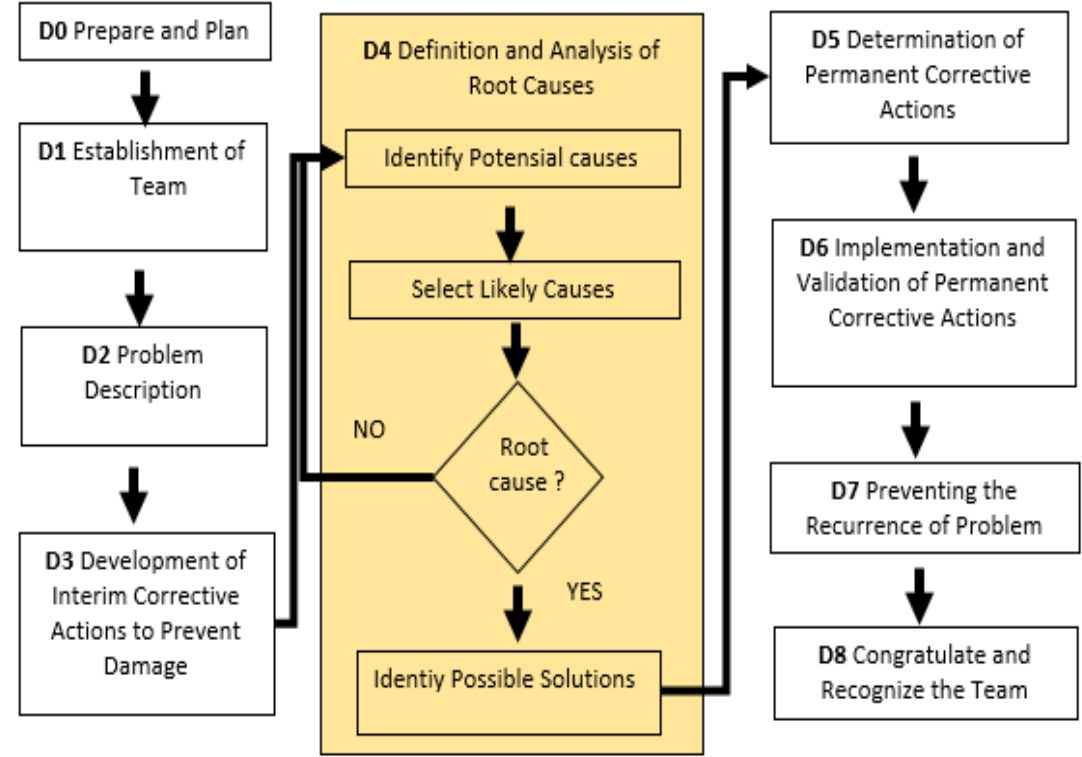

Figure $2.18 D$ Procedure

\section{RESULTS AND DISCUSSION}

This research tries to explore various reasons \& find solution of repeating dimension product out of spec customer claim in automotive injection plastic supplier. For the conduct of research, detailed steps were applying the 8D Method which each stage are:

\section{Step D0: Prepare and Plan for the 8D}

First step for analysis purpose, we collected in the past three months rejection data for dimension product out of specification. Dimensional variation product (dimension product out of specification) is a defect produced by the molded which part dimension varying from batch to batch or from shot to shot while the machine settings and molded remain the same. To identify process defect, Pareto analysis has been carried out. The purpose of this step was to focus on the major issue. The following table shows the procedure for collecting necessary data: 


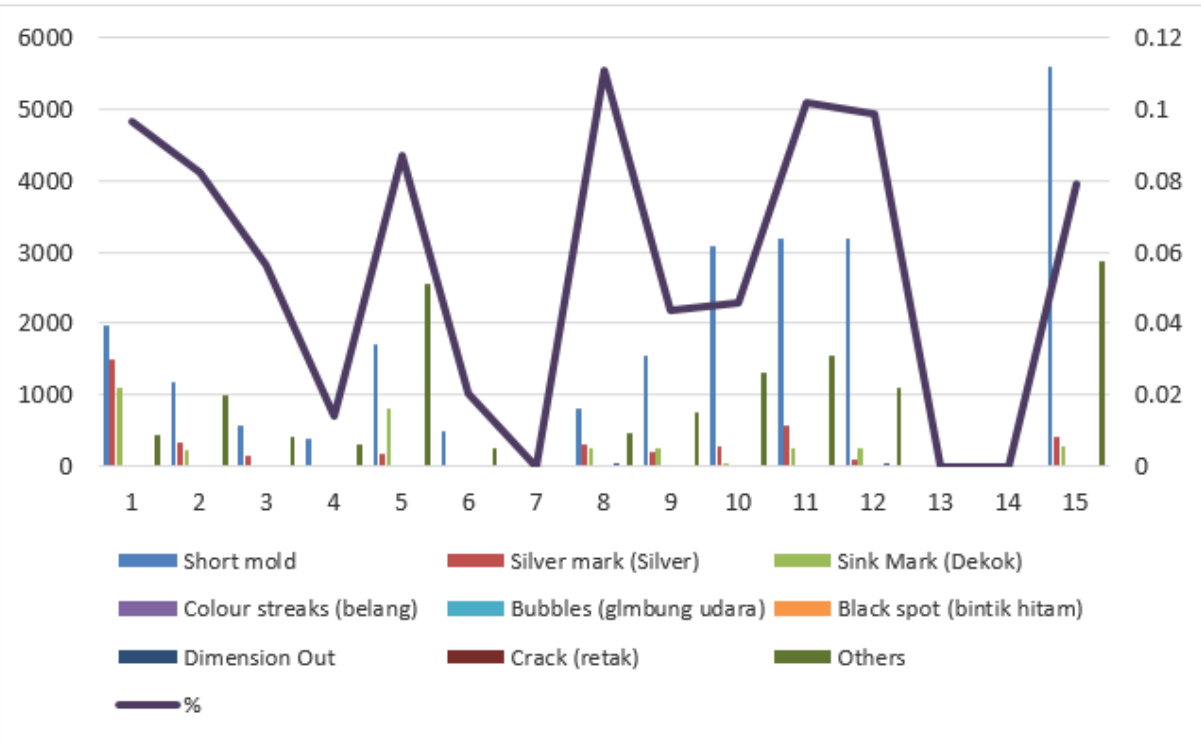

Figure 3.1 Defective breakdown by machine and defect type (Jul-Sept' 20)

\section{Step D1: Establishment of Team}

Cross functional team was formed to solve the major issue. Team leader appointed from whom the ones with problem-solving skills from different divisions or departments representing the possible origin of cause. Selected members have adequate knowledge about the process and product. They know about where the problem occurred, why the problem happened, and they have experience to solve the problem by technical disciplines skill and improve these condition by implementing several alternative solutions.

Table 3.1 D1 Team members

\begin{tabular}{|c|c|c|}
\hline Department & Name & Title \\
\hline Quality & Ely R & Quality Inspector \\
\hline Quality & Sri Anik & Quality Supervisor \\
\hline Production & Arifin & Production Manager \\
\hline Maintenance & Imam S & Maintenance Supervisor \\
\hline Production Engineer & Aditya S & Product Engineer \\
\hline Production & Sukardi K & Production Supervisor \\
\hline Purchasing/Warehouse & Irawati S & Purchasing Supervisor \\
\hline
\end{tabular}

\section{Step D2: Problem Description}

This step is one of the most important steps and it is crucial for solving the problem. Problem in details and clearly identified will be solved using this step, and this problem is specified in detail by quantifiable parameters. We are usage $5 \mathrm{~W} 2 \mathrm{H}$ tools analysis, which the form is given in table 5 below. 
Table 3.2 D2 Problem Definition

\begin{tabular}{|c|c|}
\hline Customer Name & Containment Action \\
PT XYZ Tbk & NG (scrap or reject) \\
Customer Location & Lot No. \\
Gresik Indonesia & LQ4012-10-A2020 \\
Customer Contact & Claim Status \\
Yoshima Kaneguchi & Recurrent \\
Supplier Part No & Detail Photo \\
SLO 0350041365 & \\
Part Name & \\
SLCR 30 & \\
Failure Rate or Quantity & \\
400 pcs & \\
Defect Category & \\
Major & STD : $\mathbf{3 1 0} \pm \mathbf{2}$ \\
Manufacturing Date & ACT: $\mathbf{3 0 7 . 5 2 - 3 0 7 . 5 8 ~ m m ~}$ \\
26.10 .2020 & \\
Problem Description & \\
Diameter product out spec : & \\
STD : $310 \pm 2$ & \\
ACT: 307.52 - 307.58 mm &
\end{tabular}

\section{Step D3: Development of Interim Corrective Actions to Prevent Damage}

The ultimate aim of this step is controlling the process in order to non-compliance product is not sent to the customer. This step is only as immediate protective action and often has no connection with the causes of the problem.

Table 3.3 D3 Development of Interim Corrective Actions to Prevent Damage

SPECIFIC CONTAINMENT ACTION (describe): Quality Alert was posted at production floor in order to let all section in-charges understand and know the customer quality issue.

Temporary actions to contain the problem and "fix" until permanent corrective action is in place (validate that the actions taken work)

Quality Alert in Place

Material In Process (Qty)

Material In Warehouse (Qty)

In Transit (Qty)

Customer Warehouse(Qty)

Certification Marks On Parts/

Boxes

Conforming Material Expected Date :

Marking

Method

\begin{tabular}{|c|c|c|c|} 
Yes & $x$ & No & \\
Good & NA & Bad & 0 pcs \\
Good & NA & Bad & 0 pcs \\
Good & NA & Bad & 0 pcs \\
Good & NA & Bad & 0 pcs \\
Yes & $x$ & No & 0 pcs \\
\cline { 2 - 3 } Yes & $x$ & 5 & 2020 \\
\cline { 2 - 3 } & 11 & dd & yyy
\end{tabular}

Red Marking Passed 
Step D4: Definition and Analysis of Root Causes

\section{Technical root cause analysis}

Analyze all the potential root causes of the issue carried out by engineering team and QC team. Root causes analysis is defined by one or more of the following tools 5 Why, Brainstorming or fish bone diagram as below:

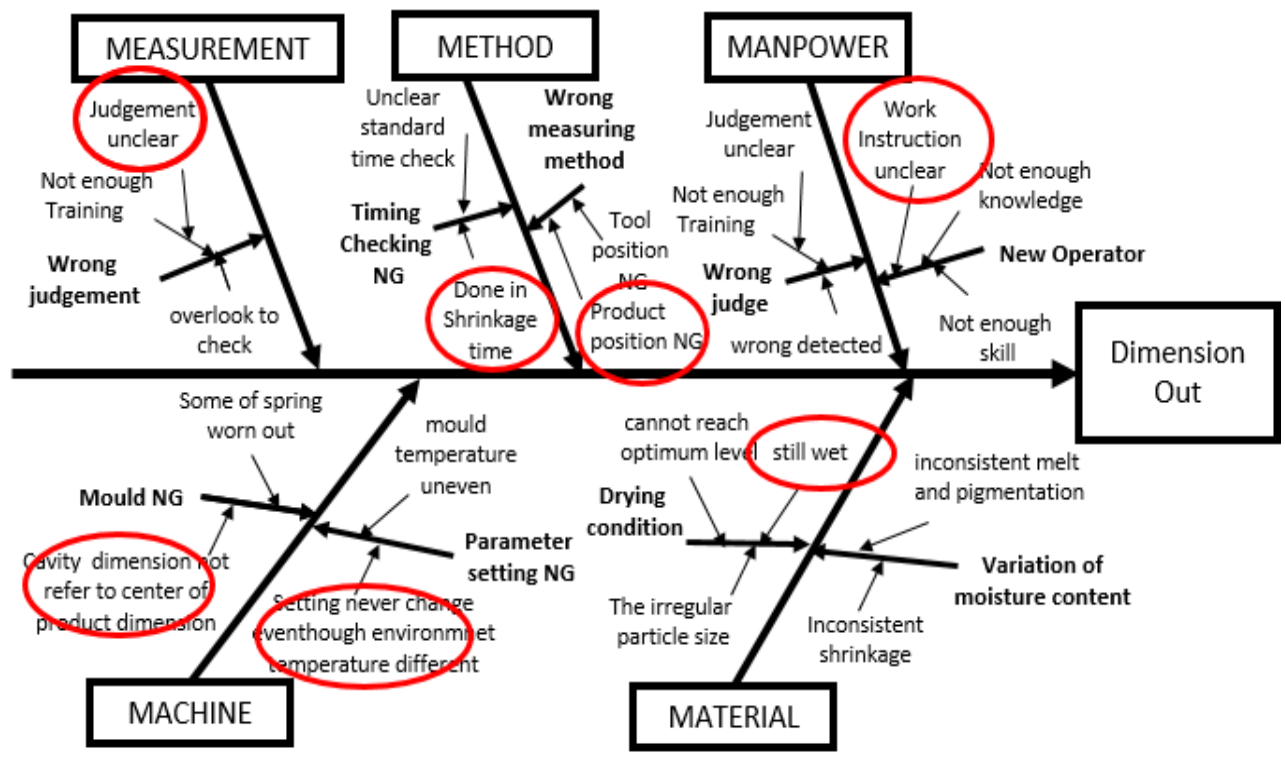

Figure 3.2 Dimension out fishbone graph

\section{Leak out 5 Why root cause analysis}

Failure mode was identified. Mold was found as a root cause to produce variation of dimension product because its design was the problem due to cavity design problem. Dimension out of specification were detected after production process.

Table 3.4 Leak Out 5Why Root Cause Analysis

\begin{tabular}{|c|c|c|c|c|c|}
\hline Leak & $\begin{array}{c}\text { Why wasn't } \\
\text { the problem } \\
\text { detected? }\end{array}$ & Why? & Why? & Why? & Why? \\
\cline { 2 - 6 } out & $\begin{array}{c}\text { Dimension } \\
\text { out of } \\
\text { specification } \\
\text { passed from } \\
\text { inspection } \\
\text { process }\end{array}$ & $\begin{array}{c}\text { Product } \\
\text { shrinkage } \\
\text { after } \\
\text { checked }\end{array}$ & $\begin{array}{c}\text { Checking was } \\
\text { performed } \\
\text { during } \\
\text { shrinkage } \\
\text { period }\end{array}$ & $\begin{array}{c}\text { Timing } \\
\text { checking did } \\
\text { not include in } \\
\text { standard } \\
\text { checking } \\
\text { method }\end{array}$ & $\begin{array}{c}\text { PFMEA was } \\
\text { developed } \\
\text { without } \\
\text { considered } \\
\text { for timing } \\
\text { control }\end{array}$ \\
\hline
\end{tabular}

Step D5: Determination of Permanent Corrective Actions

Corrective actions clearly linked to all individual root causes analysis for both failure occurrence and failure of leak out. The purpose of fifth discipline of the $8 \mathrm{D}$ is to choose the best permanent corrective action to eliminate the root cause of problem and the best permanent corrective action for the location of leakage. 
Table 3.5 D5 Determination of Permanent Corrective Actions

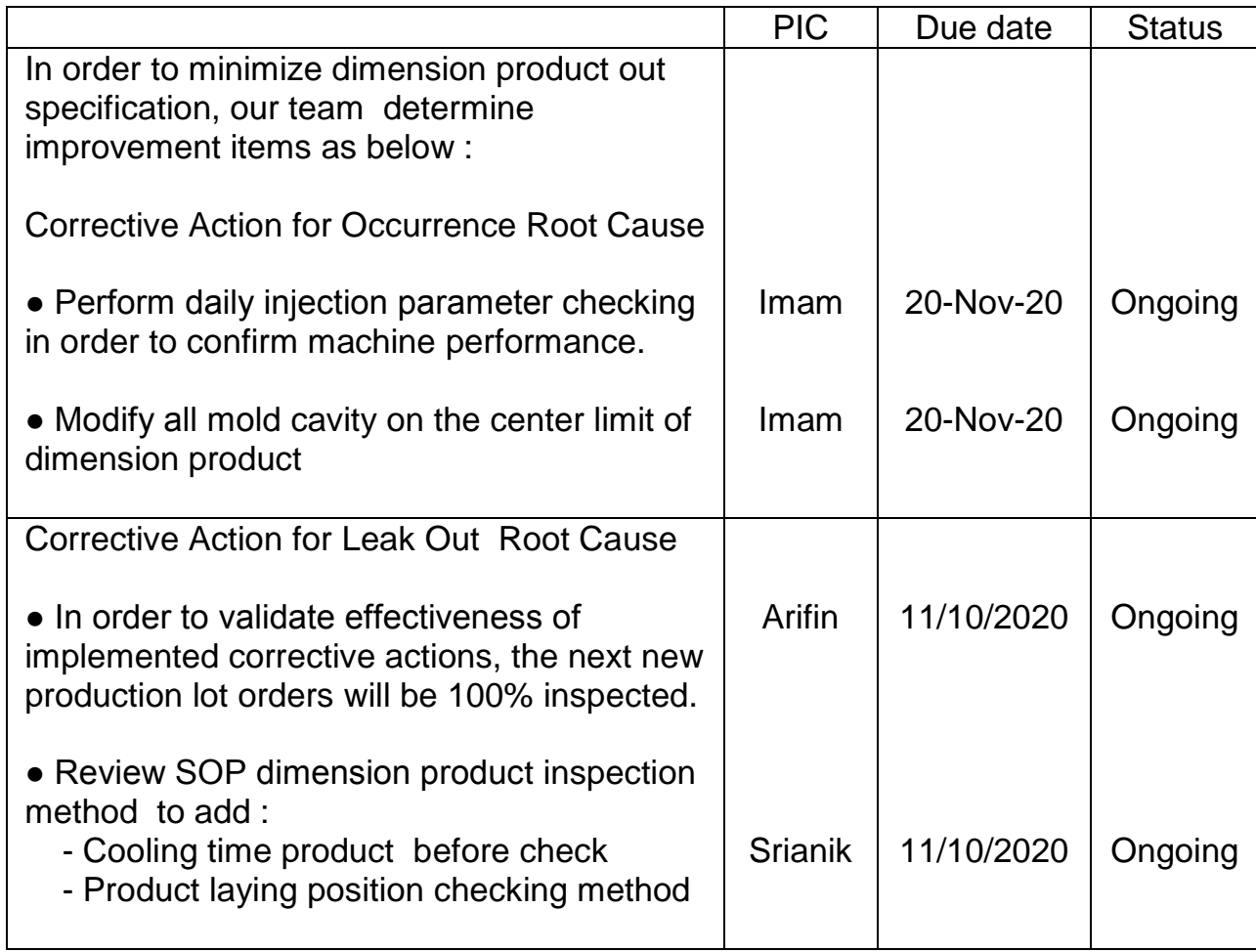

Step D6: Implementation and Validation of Permanent Corrective Actions The aim of sixth discipline of $8 \mathrm{D}$ is validating effectiveness after implementing corrective action and ensuring there are no negative consequences. Important thing is effectiveness of each corrective action was properly evaluated. Ensure there is evidence that the failure mode/defect has not reoccurred. It is detected by $100 \%$ confidence and quality of process manufacturing system were updated as a result.

Table 3.6 D6 Implementation and Validation of Permanent Corrective Actions

\begin{tabular}{|l|c|c|}
\hline \multicolumn{1}{|c|}{ Permanent Corrective Actions } & PIC & Due Date \\
\hline $\begin{array}{l}\text { - In order to validate effectiveness of implemented } \\
\text { corrective actions, the next new production lot orders } \\
\text { will be } 100 \% \text { inspected }\end{array}$ & Arifin & 10-Nov-20 \\
\hline $\begin{array}{l}\bullet \text { Perform daily injection parameter checking in order } \\
\text { to confirm machine performance. }\end{array}$ & Imam & 10-Nov-20 \\
\hline $\begin{array}{l}\text { - Review SOP dimension product inspection } \\
\text { method to add : } \\
- \text { Cooling time product before check } \\
\text { - Product laying position checking method }\end{array}$ & Srianik & 12-Nov-20 \\
\hline $\begin{array}{l}\text { - Information regarding maintenance routine will keep } \\
\text { into internal maintenance record }\end{array}$ & Imam & 9-Nov-20 \\
\hline
\end{tabular}

Step D7: Preventing the Recurrence of Problem

In this step we established preventive actions to avoid occurrence comparable problems in the other production processes and products. Also, 
we updated the necessary system including policies, practices and work procedure to prevent problem and similar ones (eg. control plan, work instruction, standard operation procedure, and inspection sheets) reoccurrence of this.

Table 3.6 D7 Preventing the Recurrence of Problem

\begin{tabular}{|c|c|c|c|c|c|}
\hline \multicolumn{3}{|c|}{ Preventing the Recurrence of Problem } & PIC & Due date & Status \\
\hline \multicolumn{3}{|c|}{$\begin{array}{l}\text { - Training to all related section with direct } \\
\text { interaction will be conducted }\end{array}$} & Maulida & 2-Nov-20 & Done \\
\hline \multicolumn{3}{|c|}{$\begin{array}{l}\text { - Implementation of corrective actions to similar } \\
\text { process }\end{array}$} & Srianik & 12-Dec-20 & Ongoing \\
\hline \multirow{2}{*}{\multicolumn{3}{|c|}{$\begin{array}{l}\text { - Patrol check by QC leader by } 2 \text { hourly } \\
\text { Review All affected document/systems }\end{array}$}} & Ely & 10-Dec-20 & Ongoing \\
\hline & & & & & \\
\hline Document & PIC & \multicolumn{2}{|c|}{$\begin{array}{l}\text { Completion } \\
\text { date }\end{array}$} & \multicolumn{2}{|c|}{ Doc .No. } \\
\hline $\begin{array}{l}\text { Corrective action } \\
\text { validation }\end{array}$ & Sri anik & \multicolumn{2}{|c|}{ 15-Dec-20 } & & \\
\hline \multicolumn{5}{|l|}{ Maintenance } & \\
\hline \multicolumn{4}{|l|}{ Maintenance } & & \\
\hline Training & Ely & \multicolumn{2}{|c|}{$17-$ Oct-20 } & & \\
\hline Update PFMEA & Ely & \multicolumn{2}{|c|}{ 13-Nov-20 } & & \\
\hline $\begin{array}{l}\text { Update Control } \\
\text { Plan }\end{array}$ & Ely & \multicolumn{2}{|c|}{$19-$ Oct-20 } & & \\
\hline \multirow{2}{*}{$\begin{array}{l}\text { Update SOP and } \\
\text { WI } \\
\text { Others (Define) }\end{array}$} & Ely & \multicolumn{2}{|c|}{ 28-Nov-20 } & & \\
\hline & & & & & \\
\hline
\end{tabular}

Step D8: Congratulate and Recognize the Team

We conducted final meeting with the $8 \mathrm{D}$ team to review and evaluation of steps D0 thru D7. Conclusion of the problem solving with agreement of the involved persons and also customer. 8D activities related to this problem finally concluded and no open or "in-progress" action items. Recognize each team member and their contributions and also obtain customer approval to formally closed the 8D's.

Table 3.7 D8 Congratulate and Recognize the Team

\begin{tabular}{|c|c|c|c|c|c|}
\hline \multicolumn{3}{|c|}{ Lessons Learned } & PIC & Due date & Status \\
\hline \multicolumn{3}{|c|}{$\begin{array}{l}\text { Dimension out of specification will be } \\
\text { improved }\end{array}$} & $\begin{array}{l}\text { All } \\
\text { section } \\
\text { related }\end{array}$ & 15-Dec-20 & Ongoing \\
\hline \multicolumn{3}{|c|}{$\begin{array}{l}\text { - Set up meeting to review the implementation } \\
\text { of each corrective action, and then close the } \\
8 D \text { 's report }\end{array}$} & Arifin & 16-Dec-20 & Ongoing \\
\hline \multicolumn{6}{|c|}{ Management review and approval } \\
\hline Yes/No & Tittle & \multicolumn{2}{|c|}{ Name } & \multicolumn{2}{|c|}{ Date } \\
\hline Yes & Quality Manager & \multicolumn{2}{|c|}{ Suyitno } & \\
\hline Yes & Plant manager & \multicolumn{2}{|c|}{ Hendra S } & \multicolumn{2}{|c|}{$20-$ Dec-20 } \\
\hline
\end{tabular}

\section{CONCLUSIONS}

After implementing permanent corrective and preventive actions and closing the 8D activity were observed in next 5 days production lots for the issue of dimension out of specification, the total rejection reduces from $0.07 \%$ to $0.01 \%$. In terms of customer 
complaints need to be monitoring continuously until the improvements that have been made prove effective.

\section{REFERENCES}

[1] Ehie, I. C. and Sawhney, R. Integrating Six Sigma and Lean Manufacturing for Process Improvement: A Case Study. In Badiru, A. B., Handbook of industrial and systems engineering. CRC Press, ch. 2006. 36:1-36:12.

[2] Carlos A. Riesenberger and Sérgio D. Sousa. The 8D Methodology: An Effective Way to Reduce Recurrence of Customer Complaints?.Proceedings of the World Congress on Engineering 2010. Vol III.

[3] Rambaud, L. 8D Structured Problem Solving: A Guide to Creating High Quality 8D Reports. Phred Solutions, Breckenridge, CO, USA. 2006.

[4] Bosch, V.G. and Enriquez, F.T.TQM and QFD: exploiting a customer complaint management system. International Journal of Quality \& Reliability Management. 2005, Vol. 22 No. 1.

[5] Lalit Kumar Biban, Deepak Dhounchak, Shakti. 8D Methodology: From Concept to Application Across Manufacturing Industries. IJSRSET. 2017. Volume 3 Issue 6 Print ISSN: 2395-1990 Online ISSN: 2394-4099.

[6] V. Alexa,I. Kiss.Complaint Analysis Using 8d Method Within The Companies In The Field Of Automotive. Analecta Technica Szegedinensia review of faculty of engineering.2016. Vol. 10, No.1.

[7] Keppmann.Hella 8D Report_Supplier Training Material. Lippstadt 2017-11-20 HCC-PUQM

[8] Küster, B. Eilert, B. Overmeyer L. Automated Quality Evaluation of $8 D$ Reports in Context of Complaint Processing. In: Proceedings of Symposium on Automated Systems and Technologies. 2016. Vol. 3. pp. 77-80

[9] Zahrami, A. and Benbow, D. Introduction to 8D Problem Solving: Including Practical Applications and Examples. ASQ Quality Press. Milwaukee, Winsconsin.2017

[10] Marcus Larsson Martin Norén. Assessment and improvement of Volvo Powertrain"s problem solving process "Quality Journal" vs. "Six Sigma". Department of Technology Management and Economics Division of Quality Sciences Chalmers University of Technology Göteborg, Sweden. 2011. 